\title{
Better Preparing Students for Materials Classes
}

\author{
William Jordan and Norm Pumphrey \\ Louisiana Tech University
}

\begin{abstract}
In the fall of 1999, the six engineering programs at Louisiana Tech University implemented new curricula that integrated math and specific engineering courses that all freshmen and sophomore engineering students take. Previous program-level materials courses were combined. We created a new materials course that is taken by sophomore students from five of our six engineering disciplines.

This materials class is closely integrated with the math and statics/strength courses that the students take at the same time. In the Fall 1999 quarter, all sophomore students were put into these new courses, regardless of whether they had taken the integrated freshman courses. The students who have taken the materials course during the last two years are in two different groups: one that has had the integrated curriculum background and one that has had a traditional background.
\end{abstract}

We wanted to examine two different aspects about this new curriculum. The first aspect is whether we are more effectively teaching materials engineering with our new course. The second aspect is whether the new integrated curriculum better prepares the students for our materials course. We believe that the new materials course is a better educational experience for the students, and so reported in our 2000 ASEE paper ${ }^{1}$. This paper concentrates on the second aspect: the effect of the students' backgrounds on their performance in the materials class.

The common materials course was taught to three sections (83 students) in the Fall 1999 quarter. However, the small percentage of integrated students (about 25\%) caused us to expand our study to include the students who are taking the course in the Fall 2000 quarter. Seventy-five students in two separate sections completed the course. There was a more even mix of students with the integrated and nonintegrated backgrounds in the sections (38 are integrated while 37 are traditional).

Our ASEE paper presented at the 2000 Conference described this new materials course in some detail. ${ }^{1}$ This paper uses data from both years and emphasizes the issue of how the students' backgrounds affect their performance in the materials course. The students in the integrated curriculum continue to show superior performance when compared to students from the traditional background, indicating that the freshman integrated curriculum better prepares a student for success in a required follow-up course.

"Proceedings of the 2001 American Society for Engineering Education Annual Conference \& Exposition Copyright $\odot 2001$, American Society for Engineering Education” 


\section{Background on the Freshman Integrated Curriculum}

During the past four years, the College of Engineering and Science at Louisiana Tech University has implemented an innovative freshman engineering curriculum that students from all six of the represented disciplines are required to complete. This curriculum basically involves a three-quarter sequence of two semester credit hour ( $\mathrm{SCH}$ ) Engineering Problem Solving courses that are taught in tandem with a three-quarter sequence of three SCH Engineering Math courses. Additionally, students are required to take two Chemistry courses and a Physics course spread over the same three quarters.

In the Fall 1997 quarter, a pilot group of 40 students began the initial process of learning in math, chemistry, and engineering problem solving classes in which integration was first attempted. These classes established the foundation of the current freshman integrated curriculum. During the next fall, the curriculum was retooled and was taught to a group of 120 freshmen. At the same time, the original pilot group became the pilot group for the sophomore integrated curriculum. Dr. Jordan taught a preliminary version of the current materials course to this pilot group.

Finally, beginning in the Fall 1999 quarter, all incoming freshmen were required to participate in the new freshman curriculum and the old freshman curricula established by the individual programs were eliminated. More details of the early experiences have been discussed by Nelson and Napper. ${ }^{2}$

\section{The Current Materials Course and Companion Labs}

The new materials lecture course (MEMT 201 -- Engineering Materials) replaced two lecture courses taught separately by the Mechanical Engineering (ME) and Civil Engineering (CE) programs. This twohour lecture course maintained the flavor of the former Mechanical Engineering materials course, with a substantial amount of time being spent on a material's crystalline and atomic structures and how heat treatment affects its mechanical properties. A two-lecture sequence on portland cement concrete was added to expose all engineering students to this very important engineering material. Electrical properties of materials were covered in some detail to give students basic knowledge in this important area. Additionally, polymeric and composite materials were introduced. Details of this course were presented in our 2000 ASEE paper ${ }^{1}$.

The Mechanical Engineering and Civil Engineering programs maintained separate laboratories so that steel and polymers could be more completely explored by the MEs and so that portland cement concrete could be adequately covered by the CEs.

"Proceedings of the 2001 American Society for Engineering Education Annual Conference \& Exposition Copyright @2001, American Society for Engineering Education", 


\section{Student Performance in the Materials Course}

The new lecture course has students from five of the six engineering disciplines in the same classroom at the same time. (Chemical Engineering elected not to participate in the materials class.) The students were exposed to engineering materials from viewpoints that many would not have experienced had they taken a course with students and professors exclusively from their discipline.

In the Fall 1999 quarter, the authors taught the materials lecture class as a team to a large section of about 60 students, allowing each to be exposed to the engineering materials perspective of the other and to observe the successes and problems that were likely to occur with a diverse student audience. This provided a unique experience for all individuals and exposed, among other things, the difficulty of covering the vast material properly in the allotted class periods.

At the 2000 Annual Conference of the American Society for Engineering Education, the authors presented many of these experiences and observations and began to explore the effect that the freshman integrated curriculum might be having on the performance of students in the materials class. ${ }^{1}$ However, we realized that there was not enough information to properly assess this effect. Now that the Fall 2000 quarter is complete and additional students have completed the course from integrated and traditional (nonintegrated) backgrounds, the data continues to grow for assessing the effectiveness of the new curriculum.

In the Fall 1999 quarter, 83 undergraduate students in three sections completed MEMT 201. Of these students, 20 had experienced the freshman integrated curriculum and 63 had not. In the Fall 2000 quarter, 75 students in two sections completed the course. Of this group, 38 had just completed the new freshman curriculum and 37 had not. In this paper, the authors look at these 158 students and begin to assess how the 58 , or $37 \%$, who had the freshman curriculum background performed in the materials course compared to the other $63 \%$.

We have looked at several characteristics to allow us to make the comparisons and assessments that follow. Factors such as current overall student grade point average (GPA), grade earned in the materials class, student classification (senior, junior, or sophomore), engineering discipline, and curriculum background were used in the assessment.

It must be noted that we did not examine the students background (integrated/traditional) until after the class was over. This removes any implicit bias on the part of the instructors. All of the students in the new materials course were taught in the same manner, without regard to their background.

Table 1 shows the general performance results of students from the two quarters, and 5 sections, of materials science. The authors taught all of these sections and attempted to make them as nearly the same as possible by giving the same homework assignments and exams. However, we recognize that

"Proceedings of the 2001 American Society for Engineering Education Annual Conference \& Exposition Copyright (C2001, American Society for Engineering Education" 
our different styles of teaching have a definite effect on how the students learn.

Note that students typically made grades, on the average, that were lower than their average GPA. However, it is interesting to note that the difference between the GPA and the course average decreased from Fall 1999 to Fall 2000. This difference prompted us to consider the possible effects that might be attributed to the integrated curriculum, since a higher percentage of the students in Fall 2000 had been through our integrated curriculum

\begin{tabular}{|c|c|c|c|}
\hline \multicolumn{4}{|c|}{ Table 1 } \\
\hline $\begin{array}{c}\text { Group } \\
\text { Considered }\end{array}$ & $\begin{array}{c}\text { Avg. } \\
\text { Overall GPA }\end{array}$ & $\begin{array}{c}\text { Avg. MEMT 201 } \\
\text { Grade }\end{array}$ & $\begin{array}{c}\text { No. of Students } \\
\text { in Group }\end{array}$ \\
\hline All Students & 3.02 & 2.44 & 158 \\
\hline Fall 2000 (2 sections) & 3.10 & 2.72 & 75 \\
\hline Fall 1999 (3 sections) & 2.95 & 2.18 & 83 \\
\hline
\end{tabular}

In Table 2 the information from Table 1 has been expanded to show the breakdown among student curriculum backgrounds. There are almost twice as many nonintegrated students as integrated students. While the overall GPA within the two groups is very consistent from one quarter to the next, the difference in overall GPA between the two groups is quite large. The integrated curriculum students have almost a 0.5 higher average GPA than the nonintegrated group. Since the students for the integrated curriculum were not pre-selected, this indicates that the integrated curriculum itself is leading to better grades (and hopefully more learning).

When we consider the difference between the average overall GPA and the average grade earned in the materials class, we note that, while both groups generally make lower grades in the class than their GPAs show, the integrated group has a much smaller difference $(0.17)$ than the nonintegrated group (0.82). The integrated students performed better in our materials course.

Table 2 also shows that the average grade for each group in the materials class is less than the average overall GPA for that group, except for the Fall 1999 integrated group. Why did that Fall 1999 group show a slightly opposite trend? Two factors made this group of integrated students different from the ones that followed them. First, virtually all of the integrated students during the Fall 1999 quarter were from the second-year integrated pilot program. These pilot group students tended to develop a professional rapport in their freshman year better than the fully integrated freshmen classes that came after them. Secondly, the integrated students from the Fall 1999 quarter were placed in a separate section from most of the nonintegrated students. Thus, they were better able to continue working

"Proceedings of the 2001 American Society for Engineering Education Annual Conference \& Exposition Copyright @2001, American Society for Engineering Education", 
together and supporting each other on homework and other assignments, as they were taught to do in the freshmen integrated curriculum classes. These two differences might have helped the Fall 1999 integrated group to perform better in the materials class than the other groups.

\begin{tabular}{|l|c|c|c|}
\hline \multicolumn{5}{|c|}{ Table 2 } \\
\hline $\begin{array}{c}\text { Group } \\
\text { Considered }\end{array}$ & $\begin{array}{c}\text { Avg. } \\
\text { Overall GPA }\end{array}$ & $\begin{array}{c}\text { Avg. MEMT 201 } \\
\text { Grade }\end{array}$ & $\begin{array}{c}\text { No. of Students } \\
\text { in Group }\end{array}$ \\
\hline \multicolumn{4}{|c|}{ Integrated } \\
\hline All Students & 3.31 & 3.14 & 58 \\
\hline Fall 2000 (2 sections) & 3.30 & 3.00 & 38 \\
\hline Fall 1999 (3 sections) & 3.35 & 3.40 & 20 \\
\hline & 2.85 & 2.03 & 100 \\
\hline All Students & 2.89 & 2.43 & 37 \\
\hline Fall 2000 (2 sections) & 2.83 & 1.79 & 63 \\
\hline Fall 1999 (3 sections) & & & \\
\hline
\end{tabular}

Table 3 provides information that gives an interesting look at how students in different programs perform in MEMT 201. We need to consider the classification of the students that complete the course in each of the disciplines. The biomedical and industrial engineers generally do not need to complete the course early in their careers at Louisiana Tech, so many of them wait until they are seniors to enroll. These two disciplines also have the greatest differential between average overall GPA and average MEMT 201 grade. However, these 21 students are a very small percentage (13\%) of the total from the last two fall quarters.

"Proceedings of the 2001 American Society for Engineering Education Annual Conference \& Exposition Copyright $@ 2001$, American Society for Engineering Education" 


\begin{tabular}{|l|c|c|c|c|}
\hline \multicolumn{5}{|c|}{ Breakdown of Grades by Engineering Program } \\
\hline $\begin{array}{c}\text { Engineering } \\
\text { Program }\end{array}$ & $\begin{array}{c}\text { Avg. } \\
\text { Classification* }\end{array}$ & $\begin{array}{c}\text { Avg. Overall } \\
\text { GPA }\end{array}$ & $\begin{array}{c}\text { Avg. MEMT } \\
\text { 201 Grade }\end{array}$ & $\begin{array}{c}\text { No. of Students } \\
\text { in Group }\end{array}$ \\
\hline Biomedical & 3.71 & 2.78 & 1.93 & 14 \\
\hline Civil & 2.88 & 2.80 & 2.20 & 41 \\
\hline Electrical & 2.29 & 3.25 & 2.95 & 21 \\
\hline Industrial & 3.43 & 3.10 & 2.14 & 7 \\
\hline Mechanical & 2.43 & 3.11 & 2.54 & 75 \\
\hline
\end{tabular}

$* 4$ = Senior; 3 = Junior; 2 = Sophomore

The electrical engineers show a noticeably lower average classification than most of the other disciplines. This can be explained by the fact that the new electrical engineering (EE) curriculum has just recently added materials as a required course. As a result, only those who have enrolled in EE since the new curriculum was implemented (about two years ago) have begun to take the course. Virtually no juniors or seniors have taken it, so virtually all of the EEs are integrated students. Also, the EEs have the smallest difference (0.30) between average GPA and average MEMT 201 grade earned.

The two largest groups who are required to take MEMT 201 are the civil engineers (CE) and the mechanical engineers (ME). The CEs and MEs have differences of 0.60 and 0.57 , respectively, between the average GPA and their average MEMT grade. Unfortunately, only 10 of the $41 \mathrm{CE}$ students who have completed the materials class had also completed the freshman curriculum. On the other hand, the ME students have had 31 of 75 students finish MEMT 201 after having completed the freshman curriculum.

Because the $\mathrm{CE}$ and ME students provide the largest sample, these two disciplines were further divided into integrated and nonintegrated groups for analysis. Table 4 gives the results of this study. Both disciplines show almost all integrated students who have completed the materials class are sophomores, and that the GPA/materials grade differentials are 0.07 and 0.32 for CEs and MEs, respectively. For the nonintegrated group, the classification average is well above a junior for the CEs and approaches the junior level for the MEs. The grade difference is 0.78 and 0.76 for the civil students and mechanical students, respectively. The background of the integrated students allows them to achieve higher grades in the materials course as well as in their other courses.

"Proceedings of the 2001 American Society for Engineering Education Annual Conference \& Exposition Copyright @2001, American Society for Engineering Education" 
Table 4

Breakdown of Integrated Versus Non-integrated Students by Discipline

\begin{tabular}{|l|c|c|c|c|}
\hline $\begin{array}{c}\text { Engineering } \\
\text { Program }\end{array}$ & $\begin{array}{c}\text { Avg. } \\
\text { Classification }\end{array}$ & $\begin{array}{c}\text { Avg. } \\
\text { Overall GPA }\end{array}$ & $\begin{array}{c}\text { Avg. MEMT } \\
\text { 201 Grade }\end{array}$ & $\begin{array}{c}\text { No. of Students } \\
\text { in Group }\end{array}$ \\
\hline \multicolumn{5}{|c|}{ Integrated } \\
\hline Civil & 2.00 & 3.27 & 3.20 & 10 \\
\hline Mechanical & 2.13 & 3.32 & 3.00 & 31 \\
\hline \multicolumn{5}{|c|}{ Non-integrated } \\
\hline Civil & 3.16 & 2.65 & 1.87 & 31 \\
\hline Mechanical & 2.63 & 2.97 & 2.22 & 44 \\
\hline
\end{tabular}

Finally, Table 5 shows the breakdown of the integrated versus nonintegrated by student classification. All seniors and all but two juniors who completed the course have had the traditional background. Therefore, the sophomores present the only possibility for analysis between the integrated versus nonintegrated curricula. Of the 80 sophomores who have taken the materials course, 55 (69\%) first completed the freshman integrated curriculum. The table shows that the average MEMT grade dropped 0.19 below the average GPA for integrated curriculum sophomores, while the nonintegrated students showed a substantial drop of 0.97 .

Once again, those students who were in the integrated curriculum achieved higher grades in the materials course and in their other courses.

"Proceedings of the 2001 American Society for Engineering Education Annual Conference \& Exposition Copyright $@ 2001$, American Society for Engineering Education" 
Table 5

Breakdown of Integrated Versus Non-integrated Students by Classification

\begin{tabular}{|c|c|c|c|}
\hline Classification* & $\begin{array}{c}\text { Avg. } \\
\text { Overall GPA }\end{array}$ & Avg. MEMT 201 Grade & $\begin{array}{c}\text { No. of Students } \\
\text { in Group }\end{array}$ \\
\hline \multicolumn{4}{|c|}{ Combined } \\
\hline Senior & 2.74 & 1.92 & 26 \\
\hline Junior & 2.92 & 2.18 & 50 \\
\hline Sophomore & 3.17 & 2.73 & 80 \\
\hline \multicolumn{4}{|c|}{ Integrated } \\
\hline Senior & --- & --- & 0 \\
\hline Junior & 3.90 & 4.00 & 2 \\
\hline Sophomore & 3.30 & 3.11 & 55 \\
\hline \multicolumn{4}{|c|}{ Nonintegrated } \\
\hline Senior & 2.74 & 1.92 & 26 \\
\hline Junior & 2.87 & 2.10 & 48 \\
\hline Sophomore & 2.89 & 1.92 & 25 \\
\hline
\end{tabular}

*Two students were classified as "other" and are not included in this table.

\section{Conclusions}

In every case where comparisons could be made, the integrated student grades were substantially higher than nonintegrated student scores. Although no detailed statistical analyses have been conducted, there appears to be a positive effect of the integrated curriculum on the improvement of a student's grade in the materials course. There are several possible questions we may ask:

1. Are the professors involved in teaching the courses taking it easy on the integrated curriculum students? We believe this to be unlikely since the differences we see in our materials course results are for students in the same course, but which have different backgrounds. We reported in our 2000 ASEE paper ${ }^{1}$ that the average grades for the new materials course are about the same as they were for the previous materials course. The integrated students grades are, however, higher than the historical average. We have also had anecdotal complaints from students that we are working them too hard in the freshman and sophomore courses. This is not likely to occur if we were being too easy in our integrated courses.

"Proceedings of the 2001 American Society for Engineering Education Annual Conference \& Exposition Copyright $@ 2001$, American Society for Engineering Education", 
2. Are the students learning valuable critical thinking and teamwork skills that they weren't developing until later in the traditional curriculum? This may be very likely.

3. Are the students learning the required background material better? This is also very possible.

We recognize a need for a more rigorous analysis to more precisely determine the actual causes of these grade differences. For example, how does the fact that the integrated students hare generally lower in classification and thus closer to their freshman chemistry class, where basic crystalline structure is introduced, affect the results? How might things like part-time student population in the classes affect the performance statistics? It does appear, however, that our new integrated curriculum better prepares our students to study materials engineering. That fact, coupled with the new content and teaching methods we are using in the materials courses, indicates that the students appear to be learning more about materials engineering than they were previously.

\section{Bibliography}

1. Jordan, William and Norm Pumphrey, Development of an Integrated Materials Engineering Course, Presented at the ASEE annual meeting, Saint Louis, June 2000. In CD-Rom Proceedings (no page numbers).

2. Nelson, J. and S. Napper, Ramping Up to an Integrated Curriculum to Full Implementation, presented at the November 1999 Frontiers in Engineering Education Conference.

Biographical information

WILLIAM JORDAN is an Associate Professor and Program Chair of Mechanical Engineering at Louisiana Tech University. He has B.S. and M.S. degrees in Metallurgical Engineering from the Colorado School of Mines. He has an M.A. degree from Denver Seminary. His Ph.D. was in mechanics and materials from Texas A \& M University. He teaches materials oriented courses and his main research area deals with mechanical behavior of composite materials.

NORM PUMPHREY is an Associate Professor of Civil Engineering at Louisiana Tech University. He holds a B.S.C.E. from Louisiana Tech, a M.S.C.E. from the University of Missouri-Rolla, and a Ph.D. in Civil Engineering from Purdue University. He teaches and researches in the materials and geotechnical areas and regularly teaches in the freshman integrated curriculum. He also coaches and referees soccer.

"Proceedings of the 2001 American Society for Engineering Education Annual Conference \& Exposition Copyright $@ 2001$, American Society for Engineering Education" 